Vol. 1, No. 1, pp. 1-2, (October 2020)

Aswan University Journal of Environmental Studies (AUJES)

Online ISSN: 2735-4237, Print ISSN: 2735-4229

Journal homepage: http://aujes.aswu.edu.eg/

Editorial.

\title{
The Role of Environmental Studies for sustainable Development
}

\author{
Ahmed Ghallab \\ Chief members AUJES \\ President of Aswan University, Egypt
}

(C) Unit of Environmental Studies and Development, Aswan University

Welcome to the first issue of Volume 1 of Aswan University Journal of Environmental Studies (AUJES). In this Editorial we would like to share some environmental achievements with you and look into the exciting future of AUJES.

The particular UN 2030 Agenda intended for sustainable development provides the bright for world peace and prosperity for all the planet and people, now in addition to instead of the near future. Typically, the agenda recognizes that finishing poverty and other deprivations must meet with strategies that reduce inequality and even improve health and education, together with spur economic growth to take in consideration climate change and preserve the oceans and forests.

For this strategy, environmental studies are an important goal that meets the UN 2030 Agenda for sustainable development. It includes different fields include the interaction of humans with the environment that helps individuals to develop living and physical environment. It is also the way we should live and how we can develop sustainable strategies to protect our environment including global warming, deforestation, and water pollution, and how to resolve challenging environmental issues affecting nature. Environmental studies connect the humanities, social sciences, actual physical sciences, commerce, and economics to address complex contemporary environmental issues. It is a broad field that builts environment, and the relationship between them, and includes the natural environment (Joni et al.,2016).

Environmental sustainability focuses on sustainable development that discusses how the natural resources and environment endures and remains diverse and productive, in which the state of air, water, and the climate are of particular concern. Environmental sustainability meets all the present requirements without diminishing or reducing the capability of future generations to meet their own needs (Shaker, 2015). It is in the news every single day as the world copes with biodiversity loss, climate change and resource scarcity. Environmental sustainability needs community to redesign their activities of daily living to be able to meet human needs while preserving the life support systems of the planet (White et al.2013; IISD Annual Report,2012). The IPCC Fifth Assessment Report gives the outlines of current knowledge concerning technical, scientific and socio-economic information about climate change, and lists options for adaptation and mitigation. 
So, the future of the Aswan University Journal of Environmental Studies (AUJES) hopes to find up-to-date researches in all fields of environmental that help the world environment clean and grow the Environmental sustainability. We encourage all researchers in universities and research institutes to publish their work in our journal.

\section{References}

Joni Adamson; William A Gleason; David N Pellow (2016) Keywords for environmental studies. New York. New York University Press ISBN 0-8147-6074-0. OCLC 933297292.

Shaker, Richard Ross (2015). The spatial distribution of development in Europe and its underlying sustainability correlations. Applied Geography. 63. p. 35.

White, F; Stallones, L; Last, JM. (2013). Global Public Health: Ecological Foundations. Oxford University Press. ISBN 978-0-19-975190-7.

IISD Annual Report (2012) Bringing human health and wellbeing back into sustainable development. http://www.iisd.org/pdf/2012/annrep_2011_2012_en.pdf. 